

\title{
Keywords
}

ASB10; glaucoma; protein degradation; SOCS proteins; autophagy; ubiquitin; retinal ganglion cells

\footnotetext{
* Corresponding author: Kate E. Keller, PhD, Tel: 503494 2366, Fax: 503418 2399, gregorka@ohsu.edu.

Publisher's Disclaimer: This is a PDF file of an unedited manuscript that has been accepted for publication. As a service to our customers we are providing this early version of the manuscript. The manuscript will undergo copyediting, typesetting, and review of the resulting proof before it is published in its final citable form. Please note that during the production process errors may be discovered which could affect the content, and all legal disclaimers that apply to the journal pertain.
} 


\section{The GLC1F gene}

Primary open angle glaucoma (POAG) remains a leading cause of irreversible blindness (Quigley, 2011). Identification of genes impacting glaucoma has been a long and torturous path due to the heterogeneity and complexity of the disease. Family studies utilizing pedigrees, where a large majority of relatives are afflicted, have been the standard for identifying novel genes. Using this approach, we identified a glaucoma locus, $G L C 1 F$, on chromosome 7q35-q36 in an Oregon family with nine individuals with glaucoma encompassing 4 generations (Wirtz et al., 1999). All affected individuals had elevated (>22 $\mathrm{mmHg}$ ) intraocular pressure (IOP). Sequencing all of the genes in the region, a synonymous mutation in ankyrin repeat and SOCS box containing-10 (ASB10), T255T, was identified in all nine affected individuals (Pasutto et al., 2012). This mutation, rs104886478, has a frequency of $0.04 \%$ in the ExAc Aggregated Population. The finding that this variant is extremely rare and segregates with POAG in this family supports our hypothesis that ASB10 is a POAG susceptibility gene. Analysis of $A S B 10$ variants in POAG cohorts from the USA and Germany identified 26 amino acid changes in 70 patients accounting for $6 \%$ (70 of 1172 ) of the glaucoma population compared to $2.8 \%$ in the control group (Pasutto et al., 2012). Thus, a significant difference was found between patients and controls $[P=0.008$, two-tailed Fisher's exact test; odds ratio $(\mathrm{OR})=2.2,95 \%$ confidence interval $(\mathrm{CI})=$ 1.14-3.0)]. The non-synonymous amino acid changes are distributed over the entire protein sequence impacting the N-terminus, the ankyrin repeats and the SOCS box.

Since our original identification, two subsequent studies have been published. In the first, eleven non-synonymous $A S B 10$ variants were identified in a small cohort of 158 POAG patients and 82 control subjects from Iowa (Fingert et al., 2012). However, comparison of the allele frequency of each of the non-synonymous $A S B 10$ variants between the patients and controls showed that none was statistically more common in patients $(P>0.05)$. This paper has led to controversy over whether $A S B 10$ is a glaucoma-associated gene. A more recent report using a Pakistani cohort identified ten non-synonymous variants in 208 sporadic POAG patients and 151 healthy controls (Micheal et al., 2015). A burden test showed that there was a significant difference between the two groups $(p=0.0005)$. Furthermore, screening of 30 POAG families identified three rare non-synonymous variants. While these variants did not segregate with disease in the three families, one family member was homozygous for the p.Arg453Cys mutation and had a much more severe phenotype compared to his sibs. Diagnosed with POAG at the age of 15, he subsequently lost vision in both eyes at age 35 in spite of having two trabeculectomies to control the IOP of both eyes (Micheal et al., 2015). This homozygous mutation lies in the functional site of the SOCS box of ASB10 (see later).

Collectively, the three studies show that non-synonymous variants were detected in $106 / 1468$ (7.2\%) patients and in 18/694 (2.6\%) controls subjects, excluding the common variants (rs62489646, rs919533 and rs201566253) (Micheal et al., 2015). Combining these studies results in a significant difference $(P=0.000006)$ in the association of rare $A S B 10$ variants in POAG patients compared to controls (Micheal et al., 2015). Additional population studies, as well as molecular research, will be required to determine $A S B 10$ 's role in glaucoma. 


\section{The ASB family of SOCS-box containing proteins}

The family of suppressor of cytokine signaling (SOCS)-box containing proteins has over 70 members (Piessevaux et al., 2008). All SOCS-box containing proteins are involved in ubiquitination of target proteins for proteasomal-mediated protein degradation. This family is categorized into the several sub-groups depending on what protein domain the SOCS box is linked to: the SOCS family, which are linked to Src homology 2 (SH2) domains; the WSB family, proteins that contain WD-40 repeats; SSB proteins, which have Spry domains; the RAR group, which have GTPase domains; and the ASB family, which contain ankyrin repeats (Hilton et al., 1998; Nicholson and Hilton, 1998). ASB10 is one of 18 members of this sub-group (Kile et al., 2000). Members have common structural motifs including a unique N-terminal domain, a varying number of central ankyrin repeat domains and a SOCS box domain at the $\mathrm{C}$-terminus. Each of these domains has distinctive functions, which we will now describe in more detail.

\subsection{The $\mathrm{N}$-terminus}

The $\mathrm{N}$-terminal region is the most divergent at the amino acid level and there is no consensus structural motif between family members. In ASB10, alternative mRNA splicing of exon 1 results in two protein isoforms called variant 1 (v1) and variant 3 (v3) (Pasutto et al., 2012). The function of the unique N-terminal regions is unknown, but POAG-associated mutations are detected in exon 1 of both of these alternatively spliced variants suggesting that they serve important biological functions (Marrs et al., 2013; Micheal et al., 2015; Pasutto et al., 2012). We performed bioinformatics analyses of the primary amino acid sequence of V1 and V3 (Fig. 1). These analyses predicted that V1 has a signal peptide and its N-terminus is likely located outside the cell. Conversely, the V3 isoform was not predicted to have a signal peptide and its $\mathrm{N}$-terminus is likely located intracellularly. From these predictions, it appears that these two isoforms may perform different biological functions.

\subsection{The ANK repeats}

Ankyrin (ANK) repeats are one of the most common structural motifs in proteins (Mosavi et al., 2004; Mosavi et al., 2002). Each repeat, of approximately 33 residues, folds into a helixloop-helix structure with the loop region projecting outward from the helices at a $90^{\circ}$ angle. When multiple ANK repeats are stacked together, the loops form a concave L-shaped recognition face that binds specific proteins. The number and structure of ANK repeats contribute to the interaction with their substrates (Mosavi et al., 2002). For instance, the ANK repeats of ASB3 interact with tumor necrosis factor-alpha receptor-2 (TNFaRII), while ASB9 ANK repeats bind creatine kinase B (Chung et al., 2005; Debrincat et al., 2007). The interaction between ASB11 and ribophorin 1 appears to be dependent on the fourth of six ANK repeats (Andresen et al., 2014). Yet, for the majority of the ASB proteins including ASB10, the protein bound by the ANK repeats has not been identified.

The T255T mutation identified in the Oregon family is predicted to impact the number of ANK repeats in the resultant protein. The mutation is at the center of an exon splice enhancer site (Pasutto et al., 2012). Sequencing of $A S B 10$ mRNA from four of the affected 
family members revealed that exon 3 was skipped, which results in an altered reading frame and introduction of a stop codon in exon 4 . The predicted mutant protein would have only two of the seven ankyrin repeats and the SOCS box would be completely absent. Analysis of the ASB 10 protein produced from lymphoblasts from one of the affected family members showed the full-length product as well as smaller molecular weight bands (Pasutto et al., 2012). Since each of the affected individuals is heterozygous for the mutation, they have both normal and mutant ASB10 protein.

\subsection{The socs box}

The C-terminal SOCS box of approximately 40 amino acids is the most conserved motif in ASB proteins (Kile et al., 2002). The function of the SOCS box is to recruit components of the ubiquitin $(\mathrm{Ub})$ ligase complex to ubiquitinate the substrate bound to the ANK repeats for degradation (Kile et al., 2002; Piessevaux et al., 2008). ASB proteins use ubiquitination to promote the turnover of their bound substrate. Thus, SOCS box-containing proteins have been implicated as negative regulators of cell signaling.

The multi-subunit Ub ligase complex include a platform protein (Cullin), a RING family protein (Rbx) and an adapter protein (elongin BC) (Kohroki et al., 2005). ASBs 1, 2, 6, 7 and 12 bind to cullin 5 (CUL5) and RING box protein-2 (RBX2) (Kohroki et al., 2005). Furthermore, a recent study used proteomics to confirm that CUL5 and RBX2 bind to ASB10 (Andresen et al., 2014). The CUL5-RBX2 ligase complex is categorized as an E3 ubiquitin ligase (Lamsoul et al., 2016). Because ubiquitination by E3 ligases control entry into the ubiquitination-mediated protein degradation pathways, these are promising targets for the development of therapeutic interventions. Several drugs targeting CUL5-RBX E3 ligases are currently in clinical trials for the treatment of some solid tumor and hematologic malignancies (Lamsoul et al., 2016; Zhao and Sun, 2013).

Primary amino acid sequence analysis of the ASB10 SOCS box shows the presence of CUL5 and Elongin BC consensus binding sequences (Fig. 2) (Kohroki et al., 2005). Interestingly, a putative POAG mutation (R438C) resides at the center of the CUL5 binding motif (Pasutto et al., 2012). Furthermore, a Pakistani individual with a particularly severe form of glaucoma was homozygous for this mutation (named R453C in their study) (Micheal et al., 2015). Because the R438C mutation sits at the center of the CUL5 binding site, it could disrupt recruitment of CUL5 to the SOCS box. It is conceivable that the substrate bound to the ANK repeats would not be ubiquitinated properly and entry into the degradation pathways would be limited. Alterations in proteolytic degradation activity might therefore predispose POAG patients to an accumulation of cellular ASB10 and/or its bound substrate(s).

\section{ASB10 expression and function}

\subsection{ASB10 expression}

Little research has been performed on ASB10. One study showed high mRNA expression in skeletal muscle and heart (Kile et al., 2001). Another study showed that ASB10 protein was present in caveolin-1-enriched fractions of keratinocytes (Lemaitre et al., 2005). Screening 
of ocular tissues revealed that ASB10 mRNA was expressed in several ocular tissues including trabecular meshwork (TM), iris, ciliary body, retina, choroid, lamina cribrosa, and the optic nerve, but not the cornea or the lens (Pasutto et al., 2012). Of these, the TM and retina are particularly relevant to glaucoma since the TM regulates intraocular pressure (IOP) and axonal degeneration of RGCs is a characteristic phenotype of glaucoma. Indeed, RNAi gene silencing of ASB10 decreases outflow in anterior segment perfusion culture (Keller et al., 2013; Pasutto et al., 2012). These studies used two different shRNAs, which targeted exon 2 or exons 5-6 that are common to all ASB10 alternative transcripts. Since ASB10 was originally mapped in a POAG family with elevated IOP, our studies suggest that ASB10 functions in the conventional aqueous humor outflow pathway and support a role for ASB10 in IOP homeostasis.

\subsection{ASB10 and ubiquitin-mediated protein degradation pathways}

Proteins targeted for degradation are tagged with ubiquitin. Polyubiquitin chains are built by transferring ubiquitin molecules onto specific lysine (K) residues (Pickart, 2000). Two such linkages are at $\mathrm{K} 48$ and $\mathrm{K} 63$. K48-linked polyubiquitin chains are sorted into the ubiquitinproteasomal (UPS) degradation pathway, while those tagged with K63-linked ubiquitin are degraded by the autophagic-lysosomal (AL) pathway (Fig. 3) (Tan et al., 2008). We used Klinkage-specific antibodies (Newton et al., 2008) to show that ASB10 is associated with biomarkers of both the UPS and AL degradation pathways in cells (Keller et al., 2013). These two pathways work reciprocally to clear proteins destined for degradation: Inhibition of one pathway activates the other pathway (Pandey et al., 2007). Our recent results show that if you inhibit the proteasomal pathway using MG132, outflow resistance is increased in human anterior segment perfusion culture (Keller et al., 2013). Thus, these degradation pathways appears to play a role in the IOP regulation.

The involvement of ASB10 in protein degradation pathways was further strengthened by a recent study identifying proteins that interact with ASB10 (Andresen et al., 2014). The open-reading frame was cloned into an expression vector and transfected into 4 different cell lines that had been labeled with SILAC (stable isotope labeling by amino acids in cell culture). After 48 hours, 22 interacting proteins were identified from immunoprecipitates using LC-MS/MS (Andresen et al., 2014). Several of these proteins are related to ubiquitinassociated degradation pathways. For instance, CUL5, RBX2, Elongin B (TCEB2) and Elongin C (TCEB1) are part of the Cullin-ring complex that interacts with the SOCS box (Fig. 2), while polyubiquitin C (UBC) is a source of ubiquitin (Thomas et al., 2013). Another ASB10-interacting protein was identified as HSPA1A, which is also known as HSP72 or HSP70. Our recent paper shows strong colocalization of HSP72 and ASB10 in intracellular vesicles (Keller et al., 2013). HSP72 is a biomarker of aggresomes, a preautophagic structure. Thus, both mass spectrometry and immunofluorescence studies show ASB10 is associated with molecules of ubiquitin-mediated protein degradation pathways.

The UPS and AL protein degradation pathways are functional in healthy cells of both the TM and the retina (Esteve-Rudd et al., 2010; Liton, 2016; Liton et al., 2009a; Munemasa and Kitaoka, 2015). Evidence is accumulating that dysfunction of these pathways in aged and glaucomatous tissues may lead to accumulation of toxic material and a progressive 
cellular decline of cellular function (Caballero et al., 2004; Liton et al., 2009c). This may be particularly detrimental for non-dividing cells such as those in the TM and the retina since the accumulated material would not be diluted by distribution to daughter cells. A recent proteomics study showed many proteins linked to the ubiquitination pathway are upregulated in hypertensive human retinas (Yang et al., 2015b). Interestingly, two up-regulated proteins identified in this hypertensive study, HSPB 1 and UBC, were identified to bind to ASB10 (Andresen et al., 2014). Because of its expression in the TM and retina and its role in proteolytic degradation pathways, it is therefore possible that mutant ASB10 may contribute to cellular dysfunction. Mechanical stresses induced by elevated IOP and/or environmental factors such as chronic oxidative stress and aberrant expression of inflammatory cytokines may also predispose these tissues to progressive functional decline (Liton et al., 2009b; Luna et al., 2009).

\section{Protein degradation pathways and other glaucoma-associated proteins}

Several recent studies have linked other glaucoma-associated molecules with the UPS and AL degradation pathways. These have been extensively reviewed elsewhere so we shall only provide a brief overview of their findings (Liton, 2016; Liton et al., 2009a; Qiu et al., 2014; Sirohi and Swarup, 2016; Ying and Yue, 2016). All of these studies suggest that the pathways work in tandem to clear proteins from cells. For instance, optineurin, a gene associated with normal tension glaucoma (Ying and Yue, 2012, 2016), is usually degraded by the proteasome pathway in retinal ganglion cells (RGCs) (Ying et al., 2010). However, mutated or over-expressed optineurin is degraded via the autophagic pathway (Shen et al., 2011). Myocilin is the archetypal glaucoma-associated gene and mutant myocilin is known to accumulate in the endoplasmic reticulum, ultimately inducing cell death (Stothert et al., 2016). In normal cells, myocilin was found to be cleared by both the UPS and AL pathways (Qiu et al., 2014). However, mutant myocilin was preferably cleared via autophagic degradation. Thus, both the UPS and AL pathways are involved in clearing glaucomaassociated proteins and there appears to be a fine balance between which of these pathways is preferentially utilized.

\section{ASB10 and other diseases}

Recently, a whole exome sequencing study identified $A S B 10$ as a gene associated with a significant increased risk of systemic sclerosis (Gao et al., 2016). This autoimmune disease is characterized by excessive collagen production in the skin and other internal organs (Murdaca et al., 2016). Several studies have correlated an increased prevalence of glaucomatous neuropathy in patients with systemic sclerosis, although there was no difference in IOP between patients and controls, which may suggest a link to normal tension glaucoma (Allanore et al., 2004; Gomes Bde et al., 2011; Yamamoto et al., 1999). Systemic sclerosis is characterized by an accumulation of connective tissue components that leads to progressive hardening and scarring of the tissue (Murdaca et al., 2016) In the glaucoma field, much recent discussion has centered on the potential of fibrosis in the TM and optic nerve head leading to decreased compliance and increased stiffness of these tissues (Last et al., 2011; McDonnell et al., 2014; Overby et al., 2014; Yang et al., 2015a). Identification of 
ASB10 mutations in glaucoma and systemic sclerosis, two diseases that are characterized by altered deposition of ECM components and increased tissue stiffness, is therefore intriguing.

\section{ASB10 and inflammatory cytokines}

While we and others have identified $A S B 10$ as a glaucoma-associated gene (Micheal et al., 2015; Pasutto et al., 2012), it is highly likely that there are additional modifiers that may impact the development and/or severity of the disease. Tumor necrosis factor-a (TNFa) has the potential for being a modifier based on its being a contributing factor in glaucoma neurodegeneration (Nakazawa et al., 2006; Tezel et al., 2001; Tezel et al., 2004; Yan et al., 2000; Yang et al., 2011). Several genetic studies have suggested an association between TNFa promoter polymorphisms and glaucoma risk (Fan et al., 2010; Lin et al., 2003; Razeghinejad et al., 2009; Wang et al., 2012). Interestingly, the TNFa (-857) variant appears to have an impact on severity of glaucoma in patients with the synonymous polymorphism Thr34Thr in optineurin (Funayama et al., 2004). Polymorphisms in the interleukin-1 (IL-1) gene cluster also appear to increase the susceptibility for developing POAG (Markiewicz et al., 2013; Mookherjee et al., 2010; Wang et al., 2006).

$\mathrm{TNF} a$ and IL-1a are inflammatory cytokines that are released following laser trabeculoplasty, a common surgical intervention for glaucoma patients (Bradley et al., 2000). Both of these cytokines increase outflow in human anterior segment perfusion culture (Bradley et al., 2006). We therefore investigated whether ASB10 expression was affected by TNFa or IL-1a treatment of human TM cells. All methods are included in the supplement. Quantitative RT-PCR showed a 3.8- and 2-fold up-regulation of ASB10 mRNA after 24 and 48 hours of TNFa treatment, respectively (n=3; Fig. 4). For IL-1a, ASB10 mRNA was significantly up-regulated $2.5-, 3.5$ - and 2.7-fold at 12, 24 and 48 hours after treatment, respectively. Western blotting of TM cell RIPA lysates confirmed the up-regulation of ASB 10 protein with TNFa or IL-1a treatment at 48 hours. We also investigated the distribution pattern in cells by immunofluorescence. Using a monoclonal antibody that recognizes the V1 variant, confocal images clearly showed an increase in endogenous v1 immunostaining after 72 hours (Fig. 4C-E). The localization of ASB10 V1 antibody appears to be on the cell surface, consistent with the prediction that the N-terminus of the V1 variant is outside the cell. Collectively, this data suggests that ASB10 expression is increased by inflammatory cytokines. We hypothesize that this increase in ASB10 expression is required to bind a specific target and send it for degradation, similar to the ASB3-TNFaRII interaction (Chung et al., 2005). It is conceivable that mutant ASB10 is unlikely to respond appropriately to inflammatory signals in the eye, which could precipitate the deleterious changes that lead to glaucomatous vision loss.

\subsection{The function of other SOCS box-containing proteins in the eye}

Other SOCS box-containing proteins also appear to play a role in inflammatory events in the eye. The SOCS family of proteins has 8 members (Piessevaux et al., 2008). SOCS1 may have a neuroprotective role in the retina as it inhibits lymphocyte recruitment during inflammatory events (Yu et al., 2011). SOCS3 is a negative regulator of the janus kinase / signal inducer and activator of transcription (JAK/STAT) pathway. SOCS3 activity has been 
linked to ubiquitin-mediated degradation of the photoreceptor rhodopsin (Ozawa et al., 2008). During retinal inflammation in SOCS3 knockout mice, the levels of rhodopsin were markedly reduced and the mice had worse visual disturbance than their wild-type counterparts. However, persistent expression of SOCS3 caused by chronic inflammation may induce insulin resistance and inhibit neutrophic factors that are essential for retinal cell survival (Liu et al., 2008).

SOCS3 also appears to negatively regulate axon regeneration because RGCs in conditional SOCS3 knockout mice had a significant increase in regeneration up to two weeks post-injury (Smith et al., 2009). Double knockouts showed that axon regeneration induced by SOCS3 deletion is largely dependent upon gp130-mediated signaling, which triggers the JAK-STAT pathway. Moreover, SOCS3 may work in synergy with phosphatase and tensin homolog (PTEN), a negative regulator of the mammalian target of rapamycin (mTOR) pathway (Sun et al., 2011). Concurrent activation of both the STAT3 and mTOR pathways appears to promote long-distance axon regeneration (Sun et al., 2011). Collectively, these studies suggest that SOCS3 expression suppress axon regeneration in the mouse eye. Interestingly, both the mTOR and STAT3 pathways suppress autophagy (Jung et al., 2010; Shen et al., 2012). Thus, it appears that autophagy may negatively regulate axon growth in the eye. However, this may be over-simplistic since several other studies have reported contradictory findings (Koch and Lingor, 2016). The role of autophagy in glaucomatous optic neuropathy and the possible role in axonal protection has recently been discussed in detail elsewhere (Munemasa and Kitaoka, 2015).

\section{Conclusions and Future studies}

While ASB10 mutations appear to contribute a rare familial form of POAG, they have the potential to identify important pathways in glaucoma. Rare familial forms of disease have been the basis for identifying important pathways in many diseases including neurodegenerative diseases, such as Alzheimer's disease and Parkinson's disease. Although $A S B 10$ mutations in POAG may be rare, identifying pathway(s) involving ASB10 should lead us to insights about glaucoma pathogenesis not only in rare Mendelian families, but also in sporadic cases of POAG. Recent functional studies on $A S B 10$, together with studies on the glaucoma-associated genes myocilin and optineurin, suggest dysfunction of the proteasomal degradation pathways may be a common feature that leads to the detrimental changes associated with glaucoma. Moreover, studies on SOCS box-containing proteins and their recruitment of the Cullin-RING E3 ligase complexes may lead to the development of novel clinical strategies for the treatment of glaucoma. Further studies on the normal function of ASB10, particularly deciphering the function of the N-terminal variants and identification of the substrate to which ASB10 binds, should provide novel data of how proteolytic degradation pathways function in the eye. Moreover, development of an $A S B 10$ null mouse, or a R438C knock-in mouse, would allow us to study the effects of $A S B 10$ on glaucoma-associated phenotypes such as IOP, RGCs, and optic disc cupping and may also serve as animal model to test glaucoma therapies. 


\section{Supplementary Material}

Refer to Web version on PubMed Central for supplementary material.

\section{Acknowledgements}

This work was supported by NIH RO1 grants EY019643 (KEK), EY011650 (MKW), EY010572 (P30 Core facility grant), and an unrestricted grant to the Casey Eye Institute from Research to Prevent Blindness, New York, NY.

\section{References}

Allanore Y, Parc C, Monnet D, Brezin AP, Kahan A. Increased prevalence of ocular glaucomatous abnormalities in systemic sclerosis. Ann Rheum Dis. 2004; 63:1276-1278. [PubMed: 15361386]

Andresen CA, Smedegaard S, Sylvestersen KB, Svensson C, Iglesias-Gato D, Cazzamali G, Nielsen TK, Nielsen ML, Flores-Morales A. Protein interaction screening for the ankyrin repeats and suppressor of cytokine signaling (SOCS) box (ASB) family identify Asb11 as a novel endoplasmic reticulum resident ubiquitin ligase. J Biol Chem. 2014; 289:2043-2054. [PubMed: 24337577]

Bradley JM, Anderssohn AM, Colvis CM, Parshley DE, Zhu XH, Ruddat MS, Samples JR, Acott TS. Mediation of laser trabeculoplasty-induced matrix metalloproteinase expression by IL-1beta and TNFalpha. Invest Ophthalmol Vis Sci. 2000; 41:422-430. [PubMed: 10670472]

Bradley JM, Rose A, Kelley MJ, Chen Y, Song K, Acott TS. Interactions between Il-1 and TNF: their effects on trabecular meshwork cells. Invest Ophthalmol Vis Sci. 2006; 47 E-abstract \#1865.

Caballero M, Liton PB, Challa P, Epstein DL, Gonzalez P. Effects of donor age on proteasome activity and senescence in trabecular meshwork cells. Biochem Biophys Res Commun. 2004; 323:10481054. [PubMed: 15381105]

Chung AS, Guan YJ, Yuan ZL, Albina JE, Chin YE. Ankyrin repeat and SOCS box 3 (ASB3) mediates ubiquitination and degradation of tumor necrosis factor receptor II. Mol Cell Biol. 2005; 25:4716-4726. [PubMed: 15899873]

Debrincat MA, Zhang JG, Willson TA, Silke J, Connolly LM, Simpson RJ, Alexander WS, Nicola NA, Kile BT, Hilton DJ. Ankyrin repeat and suppressors of cytokine signaling box protein asb-9 targets creatine kinase B for degradation. J Biol Chem. 2007; 282:4728-4737. [PubMed: 17148442]

Esteve-Rudd J, Campello L, Herrero MT, Cuenca N, Martin-Nieto J. Expression in the mammalian retina of parkin and UCH-L1, two components of the ubiquitin-proteasome system. Brain Res. 2010; 1352:70-82. [PubMed: 20638372]

Fan BJ, Liu K, Wang DY, Tham CC, Tam PO, Lam DS, Pang CP. Association of polymorphisms of tumor necrosis factor and tumor protein p53 with primary open-angle glaucoma. Invest Ophthalmol Vis Sci. 2010; 51:4110-4116. [PubMed: 20357201]

Fingert JH, Roos BR, Solivan-Timpe F, Miller KA, Oetting TA, Wang K, Kwon YH, Scheetz TE, Stone EM, Alward WL. Analysis of ASB10 variants in open angle glaucoma. Hum Mol Genet. 2012; 21:4543-4548. [PubMed: 22798626]

Funayama T, Ishikawa K, Ohtake Y, Tanino T, Kurosaka D, Kimura I, Suzuki K, Ideta H, Nakamoto K, Yasuda N, Fujimaki T, Murakami A, Asaoka R, Hotta Y, Tanihara H, Kanamoto T, Mishima H, Fukuchi T, Abe H, Iwata T, Shimada N, Kudoh J, Shimizu N, Mashima Y. Variants in optineurin gene and their association with tumor necrosis factor-alpha polymorphisms in Japanese patients with glaucoma. Invest Ophthalmol Vis Sci. 2004; 45:4359-4367. [PubMed: 15557444]

Gao L, Emond MJ, Louie T, Cheadle C, Berger AE, Rafaels N, Vergara C, Kim Y, Taub MA, Ruczinski I, Mathai SC, Rich SS, Nickerson DA, Hummers LK, Bamshad MJ, Hassoun PM, Mathias RA, National Heart, L., Blood Institute, G.O.E.S.P. Barnes KC. Identification of Rare Variants in ATP8B4 as a Risk Factor for Systemic Sclerosis by Whole-Exome Sequencing. Arthritis Rheumatol. 2016; 68:191-200. [PubMed: 26473621]

Gomes Bde A, Santhiago MR, Magalhaes P, Kara-Junior N, Azevedo MN, Moraes HV Jr. Ocular findings in patients with systemic sclerosis. Clinics (Sao Paulo). 2011; 66:379-385. [PubMed: 21552659] 
Hilton DJ, Richardson RT, Alexander WS, Viney EM, Willson TA, Sprigg NS, Starr R, Nicholson SE, Metcalf D, Nicola NA. Twenty proteins containing a C-terminal SOCS box form five structural classes. Proc Natl Acad Sci U S A. 1998; 95:114-119. [PubMed: 9419338]

Jung CH, Ro SH, Cao J, Otto NM, Kim DH. mTOR regulation of autophagy. FEBS Lett. 2010; 584:1287-1295. [PubMed: 20083114]

Keller KE, Bradley JM, Acott TS. Differential effects of ADAMTS-1, -4 , and -5 in the trabecular meshwork. Invest Ophthalmol Vis Sci. 2009; 50:5769-5777. [PubMed: 19553617]

Keller KE, Kelley MJ, Acott TS. Extracellular matrix gene alternative splicing by trabecular meshwork cells in response to mechanical stretching. Invest Ophthalmol Vis Sci. 2007; 48:1164-1172. [PubMed: 17325160]

Keller KE, Yang YF, Sun YY, Sykes R, Acott TS, Wirtz MK. Ankyrin repeat and suppressor of cytokine signaling box containing protein-10 is associated with ubiquitin-mediated degradation pathways in trabecular meshwork cells. Mol Vis. 2013; 19:1639-1655. [PubMed: 23901248]

Kile BT, Metcalf D, Mifsud S, DiRago L, Nicola NA, Hilton DJ, Alexander WS. Functional analysis of Asb-1 using genetic modification in mice. Mol Cell Biol. 2001; 21:6189-6197. [PubMed: 11509662]

Kile BT, Schulman BA, Alexander WS, Nicola NA, Martin HM, Hilton DJ. The SOCS box: a tale of destruction and degradation. Trends Biochem Sci. 2002; 27:235-241. [PubMed: 12076535]

Kile BT, Viney EM, Willson TA, Brodnicki TC, Cancilla MR, Herlihy AS, Croker BA, Baca M, Nicola NA, Hilton DJ, Alexander WS. Cloning and characterization of the genes encoding the ankyrin repeat and SOCS box-containing proteins Asb-1, Asb-2, Asb-3 and Asb-4. Gene. 2000; 258:3141. [PubMed: 11111040]

Koch JC, Lingor P. The role of autophagy in axonal degeneration of the optic nerve. Exp Eye Res. 2016; 144:81-89. [PubMed: 26315785]

Kohroki J, Nishiyama T, Nakamura T, Masuho Y. ASB proteins interact with Cullin5 and Rbx2 to form E3 ubiquitin ligase complexes. FEBS Lett. 2005; 579:6796-6802. [PubMed: 16325183]

Lamsoul I, Uttenweiler-Joseph S, Moog-Lutz C, Lutz PG. Cullin 5-RING E3 ubiquitin ligases, new therapeutic targets? Biochimie. 2016; 122:339-347. [PubMed: 26253693]

Last JA, Pan T, Ding Y, Reilly CM, Keller K, Acott TS, Fautsch MP, Murphy CJ, Russell P. Elastic modulus determination of normal and glaucomatous human trabecular meshwork. Invest Ophthalmol Vis Sci. 2011; 52:2147-2152. [PubMed: 21220561]

Lemaitre G, Gonnet F, Vaigot P, Gidrol X, Martin MT, Tortajada J, Waksman G. CD98, a novel marker of transient amplifying human keratinocytes. Proteomics. 2005; 5:3637-3645. [PubMed: 16097038]

Lin HJ, Tsai FJ, Chen WC, Shi YR, Hsu Y, Tsai SW. Association of tumour necrosis factor alpha -308 gene polymorphism with primary open-angle glaucoma in Chinese. Eye (Lond). 2003; 17:31-34. [PubMed: 12579167]

Liton PB. The autophagic lysosomal system in outflow pathway physiology and pathophysiology. Exp Eye Res. 2016; 144:29-37. [PubMed: 26226231]

Liton PB, Gonzalez P, Epstein DL. The role of proteolytic cellular systems in trabecular meshwork homeostasis. Exp Eye Res. 2009a; 88:724-728. [PubMed: 19046967]

Liton PB, Li G, Luna C, Gonzalez P, Epstein DL. Cross-talk between TGF-beta1 and IL-6 in human trabecular meshwork cells. Mol Vis. 2009b; 15:326-334. [PubMed: 19209241]

Liton PB, Lin Y, Gonzalez P, Epstein DL. Potential role of lysosomal dysfunction in the pathogenesis of primary open angle glaucoma. Autophagy. 2009c; 5:122-124. [PubMed: 19001861]

Liu X, Mameza MG, Lee YS, Eseonu CI, Yu CR, Kang Derwent JJ, Egwuagu CE. Suppressors of cytokine-signaling proteins induce insulin resistance in the retina and promote survival of retinal cells. Diabetes. 2008; 57:1651-1658. [PubMed: 18356406]

Luna C, Li G, Liton PB, Epstein DL, Gonzalez P. Alterations in gene expression induced by cyclic mechanical stress in trabecular meshwork cells. Mol Vis. 2009; 15:534-544. [PubMed: 19279691]

Markiewicz L, Majsterek I, Przybylowska K, Dziki L, Waszczyk M, Gacek M, Kaminska A, Szaflik J, Szaflik JP. Gene polymorphisms of the MMP1, MMP9, MMP12, IL-1beta and TIMP1 and the risk of primary open-angle glaucoma. Acta Ophthalmol. 2013; 91:e516-523. [PubMed: 23800300] 
Marrs, C., Garnai, SJ., Lopes, NN., Reed, DM., Branham, KE., Othman, MI., Moroi, SE., Heckenlively, JR., Pawar, HS., Richards, JE. Spatial distribution of mutations in ASB10 and MYOC. ARVO; Seattle, WA: 2013. p. 6244

McDonnell F, O'Brien C, Wallace D. The role of epigenetics in the fibrotic processes associated with glaucoma. Journal of ophthalmology. 2014; 2014:750459. [PubMed: 24800062]

Micheal S, Ayub H, Islam F, Siddiqui SN, Khan WA, Akhtar F, Qamar R, Khan MI, Hollander AI. Variants in the ASB10 Gene Are Associated with Primary Open Angle Glaucoma. PLoS One. 2015; 10:e0145005. [PubMed: 26713451]

Mookherjee S, Banerjee D, Chakraborty S, Banerjee A, Mukhopadhyay I, Sen A, Ray K. Association of IL1A and IL1B loci with primary open angle glaucoma. BMC Med Genet. 2010; 11:99. [PubMed: 20565898]

Mosavi LK, Cammett TJ, Desrosiers DC, Peng ZY. The ankyrin repeat as molecular architecture for protein recognition. Protein Sci. 2004; 13:1435-1448. [PubMed: 15152081]

Mosavi LK, Minor DL Jr. Peng ZY. Consensus-derived structural determinants of the ankyrin repeat motif. Proc Natl Acad Sci U S A. 2002; 99:16029-16034. [PubMed: 12461176]

Munemasa Y, Kitaoka Y. Autophagy in axonal degeneration in glaucomatous optic neuropathy. Prog Retin Eye Res. 2015; 47:1-18. [PubMed: 25816798]

Murdaca G, Contatore M, Gulli R, Mandich P, Puppo F. Genetic factors and systemic sclerosis. Autoimmun Rev. 2016

Nakazawa T, Nakazawa C, Matsubara A, Noda K, Hisatomi T, She H, Michaud N, Hafezi-Moghadam A, Miller JW, Benowitz LI. Tumor necrosis factor-alpha mediates oligodendrocyte death and delayed retinal ganglion cell loss in a mouse model of glaucoma. J Neurosci. 2006; 26:1263312641. [PubMed: 17151265]

Newton K, Matsumoto ML, Wertz IE, Kirkpatrick DS, Lill JR, Tan J, Dugger D, Gordon N, Sidhu SS, Fellouse FA, Komuves L, French DM, Ferrando RE, Lam C, Compaan D, Yu C, Bosanac I, Hymowitz SG, Kelley RF, Dixit VM. Ubiquitin chain editing revealed by polyubiquitin linkagespecific antibodies. Cell. 2008; 134:668-678. [PubMed: 18724939]

Nicholson SE, Hilton DJ. The SOCS proteins: a new family of negative regulators of signal transduction. Journal of leukocyte biology. 1998; 63:665-668. [PubMed: 9620657]

Overby DR, Zhou EH, Vargas-Pinto R, Pedrigi RM, Fuchshofer R, Braakman ST, Gupta R, Perkumas KM, Sherwood JM, Vahabikashi A, Dang Q, Kim JH, Ethier CR, Stamer WD, Fredberg JJ, Johnson M. Altered mechanobiology of Schlemm's canal endothelial cells in glaucoma. Proc Natl Acad Sci U S A. 2014; 111:13876-13881. [PubMed: 25201985]

Ozawa Y, Nakao K, Kurihara T, Shimazaki T, Shimmura S, Ishida S, Yoshimura A, Tsubota K, Okano H. Roles of STAT3/SOCS3 pathway in regulating the visual function and ubiquitin-proteasomedependent degradation of rhodopsin during retinal inflammation. J Biol Chem. 2008; 283:2456124570. [PubMed: 18614536]

Pandey UB, Batlevi Y, Baehrecke EH, Taylor JP. HDAC6 at the intersection of autophagy, the ubiquitin-proteasome system and neurodegeneration. Autophagy. 2007; 3:643-645. [PubMed: 17912024]

Pasutto F, Keller KE, Weisschuh N, Sticht H, Samples JR, Yang YF, Zenkel M, Schlotzer-Schrehardt U, Mardin CY, Frezzotti P, Edmunds B, Kramer PL, Gramer E, Reis A, Acott TS, Wirtz MK. Variants in ASB10 are associated with open-angle glaucoma. Hum Mol Genet. 2012; 21:13361349. [PubMed: 22156576]

Pickart CM. Ubiquitin in chains. Trends Biochem Sci. 2000; 25:544-548. [PubMed: 11084366]

Piessevaux J, Lavens D, Peelman F, Tavernier J. The many faces of the SOCS box. Cytokine Growth Factor Rev. 2008; 19:371-381. [PubMed: 18948053]

Qiu Y, Shen X, Shyam R, Yue BY, Ying H. Cellular processing of myocilin. PLoS One. 2014; 9:e92845. [PubMed: 24732711]

Quigley HA. Glaucoma. Lancet. 2011; 377:1367-1377. [PubMed: 21453963]

Razeghinejad MR, Rahat F, Kamali-Sarvestani E. Association of TNFA -308 G/A and TNFRI +36 A/G gene polymorphisms with glaucoma. Ophthalmic Res. 2009; 42:118-124. [PubMed: 19556827] 
Shen S, Niso-Santano M, Adjemian S, Takehara T, Malik SA, Minoux H, Souquere S, Marino G, Lachkar S, Senovilla L, Galluzzi L, Kepp O, Pierron G, Maiuri MC, Hikita H, Kroemer R, Kroemer G. Cytoplasmic STAT3 represses autophagy by inhibiting PKR activity. Mol Cell. 2012; 48:667-680. [PubMed: 23084476]

Shen X, Ying H, Qiu Y, Park JS, Shyam R, Chi ZL, Iwata T, Yue BY. Processing of optineurin in neuronal cells. J Biol Chem. 2011; 286:3618-3629. [PubMed: 21059646]

Sirohi K, Swarup G. Defects in autophagy caused by glaucoma-associated mutations in optineurin. Exp Eye Res. 2016; 144:54-63. [PubMed: 26302410]

Smith PD, Sun F, Park KK, Cai B, Wang C, Kuwako K, Martinez-Carrasco I, Connolly L, He Z. SOCS3 deletion promotes optic nerve regeneration in vivo. Neuron. 2009; 64:617-623. [PubMed: 20005819]

Stothert AR, Fontaine SN, Sabbagh JJ, Dickey CA. Targeting the ER-autophagy system in the trabecular meshwork to treat glaucoma. Exp Eye Res. 2016; 144:38-45. [PubMed: 26302411]

Sun F, Park KK, Belin S, Wang D, Lu T, Chen G, Zhang K, Yeung C, Feng G, Yankner BA, He Z. Sustained axon regeneration induced by co-deletion of PTEN and SOCS3. Nature. 2011; 480:372375. [PubMed: 22056987]

Tan J, Wong ES, Dawson VL, Dawson TM, Lim KL. Lysine 63-linked polyubiquitin potentially partners with p62 to promote the clearance of protein inclusions by autophagy. Autophagy. 2008; 4:251-253.

Tezel G, Li LY, Patil RV, Wax MB. TNF-alpha and TNF-alpha receptor-1 in the retina of normal and glaucomatous eyes. Invest Ophthalmol Vis Sci. 2001; 42:1787-1794. [PubMed: 11431443]

Tezel G, Yang X, Yang J, Wax MB. Role of tumor necrosis factor receptor-1 in the death of retinal ganglion cells following optic nerve crush injury in mice. Brain Res. 2004; 996:202-212. [PubMed: 14697498]

Thomas JC, Matak-Vinkovic D, Van Molle I, Ciulli A. Multimeric complexes among ankyrin-repeat and SOCS-box protein 9 (ASB9), ElonginBC, and Cullin 5: insights into the structure and assembly of ECS-type Cullin-RING E3 ubiquitin ligases. Biochemistry. 2013; 52:5236-5246. [PubMed: 23837592]

Wang CY, Shen YC, Lo FY, Su CH, Lee SH, Lin KH, Tsai HY, Kuo NW, Fan SS. Polymorphism in the IL-1alpha (-889) locus associated with elevated risk of primary open angle glaucoma. Mol Vis. 2006; 12:1380-1385. [PubMed: 17149369]

Wang CY, Shen YC, Wei LC, Lin KH, Feng SC, Yang YY, Chiu CH, Tsai HY. Polymorphism in the TNF-alpha(-863) locus associated with reduced risk of primary open angle glaucoma. Mol Vis. 2012; 18:779-785. [PubMed: 22509108]

Wirtz MK, Samples JR, Rust K, Lie J, Nordling L, Schilling K, Acott TS, Kramer PL. GLC1F, a new primary open-angle glaucoma locus, maps to 7q35-q36. Arch Ophthalmol. 1999; 117:237-241. [PubMed: 10037570]

Yamamoto T, Maeda M, Sawada A, Sugiyama K, Taniguchi T, Kitazawa Y, Oyama Z, Ichihashi N, Takagi H, Kitajima Y. Prevalence of normal-tension glaucoma and primary open-angle glaucoma in patients with collagen diseases. Japanese journal of ophthalmology. 1999; 43:539-542. [PubMed: 10672886]

Yan X, Tezel G, Wax MB, Edward DP. Matrix metalloproteinases and tumor necrosis factor alpha in glaucomatous optic nerve head. Arch Ophthalmol. 2000; 118:666-673. [PubMed: 10815159]

Yang H, Ren R, Lockwood H, Williams G, Libertiaux V, Downs C, Gardiner SK, Burgoyne CF. The Connective Tissue Components of Optic Nerve Head Cupping in Monkey Experimental Glaucoma Part 1: Global Change. Invest Ophthalmol Vis Sci. 2015a; 56:7661-7678. [PubMed: 26641545]

Yang X, Hondur G, Li M, Cai J, Klein JB, Kuehn MH, Tezel G. Proteomics Analysis of Molecular Risk Factors in the Ocular Hypertensive Human Retina. Invest Ophthalmol Vis Sci. 2015b; 56:5816-5830. [PubMed: 26348630]

Yang X, Luo C, Cai J, Powell DW, Yu D, Kuehn MH, Tezel G. Neurodegenerative and inflammatory pathway components linked to TNF-alpha/TNFR1 signaling in the glaucomatous human retina. Invest Ophthalmol Vis Sci. 2011; 52:8442-8454. [PubMed: 21917936]

Ying H, Shen X, Park B, Yue BY. Posttranslational modifications, localization, and protein interactions of optineurin, the product of a glaucoma gene. PLoS One. 2010; 5:e9168. [PubMed: 20161783] 
Ying H, Yue BY. Cellular and molecular biology of optineurin. Int Rev Cell Mol Biol. 2012; 294:223258. [PubMed: 22364875]

Ying H, Yue BY. Optineurin: The autophagy connection. Exp Eye Res. 2016; 144:73-80. [PubMed: 26142952]

Yu CR, Mahdi RR, Oh HM, Amadi-Obi A, Levy-Clarke G, Burton J, Eseonu A, Lee Y, Chan CC, Egwuagu CE. Suppressor of cytokine signaling-1 (SOCS1) inhibits lymphocyte recruitment into the retina and protects SOCS1 transgenic rats and mice from ocular inflammation. Invest Ophthalmol Vis Sci. 2011; 52:6978-6986. [PubMed: 21778271]

Zhao Y, Sun Y. Cullin-RING Ligases as attractive anti-cancer targets. Curr Pharm Des. 2013; 19:32153225. [PubMed: 23151137] 


\section{Highlights}

ASB10 variants are associated with glaucoma in USA, German and Pakistani cohorts A homozygous mutation in the SOCS box may disrupt binding to E3 ubiquitin ligase ASB10 functions in ubiquitin-mediated protein degradation pathways ASB10 is up-regulated by TNFa and IL-1a in trabecular meshwork cells 

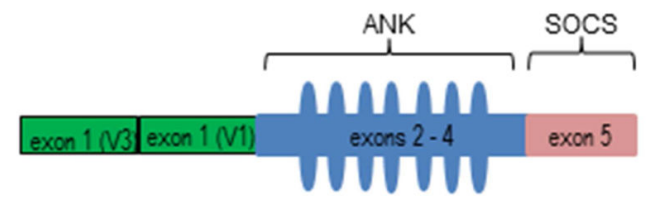

ASB10

\begin{tabular}{|c|c|c|c|c|c|}
\hline Signal peptide & Prediction & Site & A.A. & \multicolumn{1}{|c}{} \\
\cline { 1 - 4 } Variant 1 & Yes & $34-35$ & $\begin{array}{c}\text { AYT- } \\
\text { SP }\end{array}$ & \multicolumn{1}{|c}{} \\
\hline Variant 3 & No & - & - & \\
\hline Transmembrane & Prediction & Site & Score & Orientation & N-term \\
\hline Variant 1 & Yes & $12-32$ & 1235 & Outside - inside & \multirow{3}{*}{ outside } \\
\cline { 2 - 5 } & Yes & $95-115$ & 884 & Inside - outside & \\
\cline { 2 - 4 } & Yes & $352-368$ & 519 & Outside - inside & \\
\hline Variant 3 & Yes & $290-312$ & 1015 & Inside - outside & inside \\
\hline
\end{tabular}

Figure 1. Schematic of ASB10

The modular structure of ASB10 is shown: the N-terminal region (green), the 6 ANK repeats (blue) and the C-terminal SOCS box (pink). Alternative mRNA splicing of exon 1 results in two protein isoforms called V1 and V3. Bioinformatics analyses of the primary amino acid sequence shows that variant 1 has a predicted signal peptide and its $\mathrm{N}$-terminus is outside the cell, whereas V3 may not to have a signal peptide and its $\mathrm{N}$-terminus is predicted to be inside the cell. Signal peptide prediction analyses were performed at www.cbs.dtu.dk/services/SignalP/ and transmembrane predictions were performed at www.ch.embnet.org/software/TMPRED_form. 


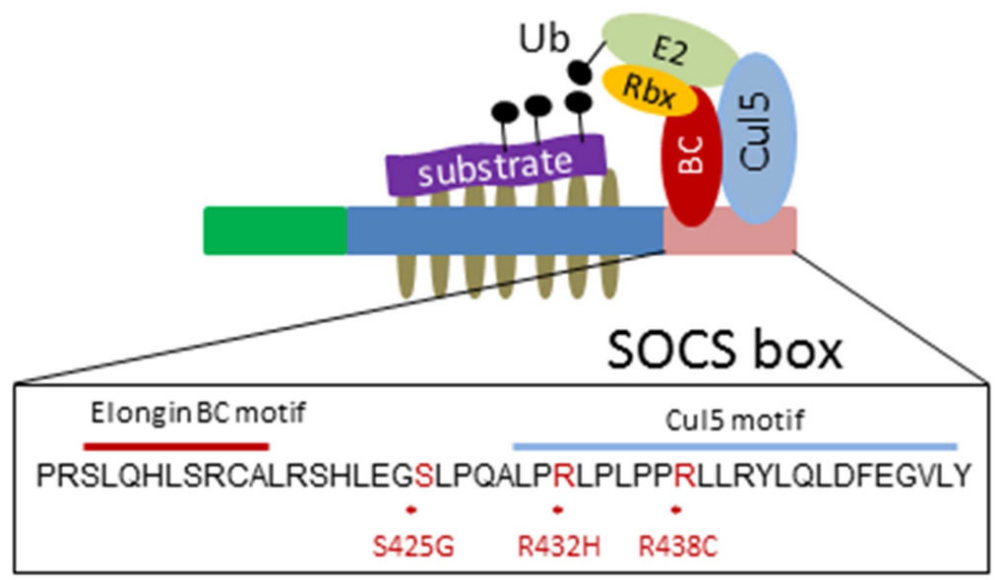

Figure 2. The SOCS box of ASB10

Schematic showing the mechanisms used by ASB proteins to ubiquitinate and degrade target substrates. ANK repeats bind to the target substrate (purple). Components of the ubiquitin ligase complex (Cullin5 (blue), Elongin BC (red), Rbx2 (yellow), E3 ubiquitin ligase (green)) are recruited by the SOCS box and these transfer ubiquitin (Ub; black) to the bound substrate. The primary sequence of the SOCS box of ASB10 is shown including the positions of three glaucoma-associated mutations. Two of these are located in the Cullin-5 binding motif. 


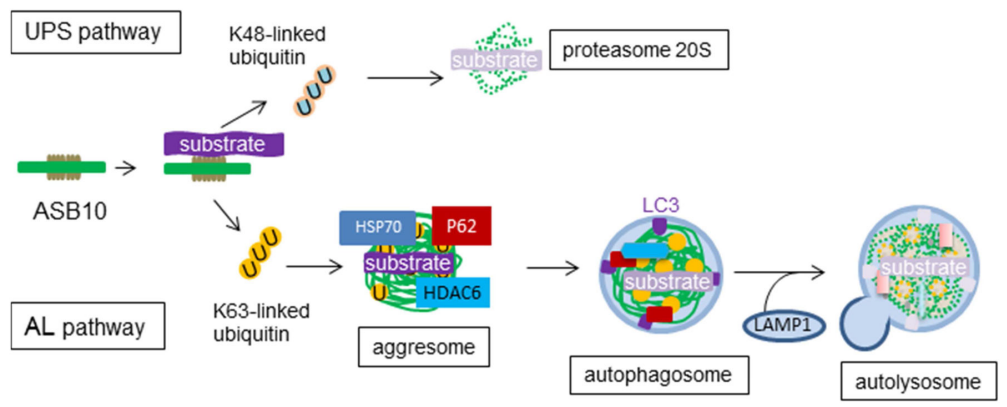

Figure 3. Ubiquitin-mediated protein degradation pathways

Schematic showing the reciprocal ubiquitin-proteasomal (UPS; top) and autophagylysosomal (AL) protein degradation pathways (bottom). ASB10 has been found to colocalize with biomarkers of both the UPS (K48-linked ubiquitin, 20S) and the AL (K63-linked ubiquitin, HSP70, P62, HDAC6, LC3, LAMP1) pathways. 

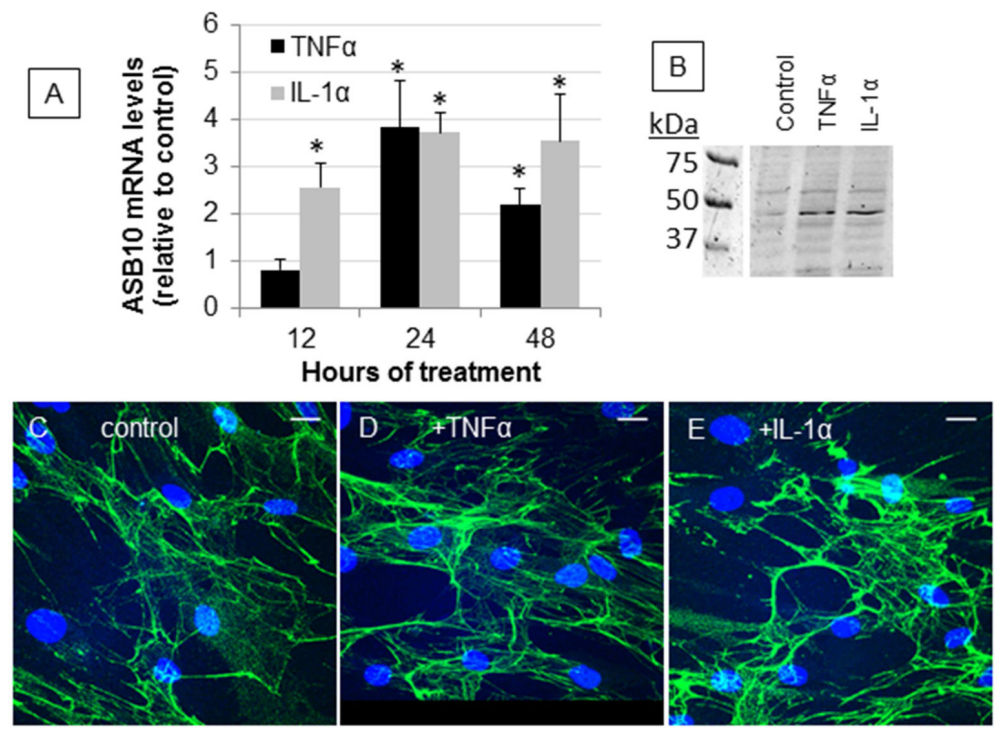

Figure 4. Effects of TNFa and IL-1a on ASB10 expression

(A) ASB10 mRNA levels were measured using quantitative RT-PCR from human TM cells treated for 12, 24 and 48 hours with $10 \mathrm{ng} / \mathrm{ml} \mathrm{TNFa}$ or IL-1a. Data shown are the average fold change compared to untreated control \pm standard error of the mean. $\mathrm{N}=3 ; * \mathrm{p}<0.05$. (B) Western immunoblotting of human TM cells treated for 48 hours with $10 \mathrm{ng} / \mathrm{ml} \mathrm{TNFa}$ or IL-1a or untreated control with an antibody recognizing the V1 variant. (C) Distribution of the V1 variant of ASB10 in human TM cells treated with $10 \mathrm{ng} / \mathrm{ml}$ TNFa or IL-1a, or untreated control for 72 hours by confocal microscopy. Confocal acquisition settings were identical for all images. Scale bar $=20 \mu \mathrm{m}$. 